\title{
Mít zájem o svůj obor a dobrý vztah ke studujícím
}

\section{How to Be Interested in Your Field of Work and Study and to Have a Good Relationship with Your Students}

\author{
Petr Hajn ${ }^{*}$
}

\begin{abstract}
Anotace
Autor statě zasvěcenou i zábavnou formou vyprávi o svém studiu na pražské právnické fakultè a zjisť̀uje, co mu toto studium prineslo pro jeho pozdèjš činnost v podnikové praxi a dlouboleté prisobeni jako pedagoga na právnické fakultě v Brnè. Prináši tak i obecnèjš podnètná zjiš́tèni o počnáni a mentalitě vysokoš̌kolských ucitelu a jejich studentù.
\end{abstract}

\section{Klíčová slova}

Vysokoškolská pedagogika; ri̊zné profesni i lidské profily vysokoškolských uăitelin; mentalita vysokoškolskéch studentui; speciálni podoby výnky práva; pomèry na vysoké škole v dobách "reálnébo socialismu“.

\begin{abstract}
The author of this contribution writes, in an informed and a very entertaining way, about bis studies at the Faculty of Law in Prague; what these studies meant to him and contributed to his later work in business practice, as well as many years of teaching at the Faculty of Law in Brno. Also, the author presents more general findings about the behavior and mentality of university teachers and their students.
\end{abstract}

\section{Keywords}

University Education; Various Professional and Human Profiles of University Teachers; Mentality of University Students; Different Forms of Teaching the Law; Standards and Life at the University in Times of "Real Socialism".

V nedávno vydaných dějinách brněnské právnické fakulty se píše, že po jejím znovuobnovení v sedmdesátých létech minulého století a odchodu některých původních profesorů přicházeli na fakultu učitelé bez pedagogické zkušenosti. Rád bych takové mínění upřesnil, pokud jde o můj př́pad a nejen o něj. Když jsem napoprvé nebyl po gymnáziu prijat na pražskou právnickou fakultu, rok jsem působil jako vychovatel na internátu střední průmyslové školy v Táboře; někteří moji „,chovanci“ byli starší než já sám. Byl jsem též činný jako pomocný instruktor v lehkoatletické škole mládeže, kde jsem mimo jiné trénoval př́ští herce Jiř́iho Hrzána a Tomáše Šolce. S nimi jsem i později

\footnotetext{
* Prof. JUDr. Petr Hajn, DrSc., emeritní profesor, Katedra obchodního práva, Právnická fakulta, Masarykova univerzita, Brno / emeritus professor, Department of Commercial Law, Faculty of Law, Masaryk University, Brno, Czech Republic / E-mail: petrhajn@volny.cz
} 
komunikoval. Uvědomoval jsem si, že kantorova přednáška se v něčem podobá hereckému výkonu - velmi při ní záleží na pohybu, modulaci hlasu i na odmlkách.

Pro mé příští pedagogické působení však ještě více znamenala skutečnost, že při studiu na pražské právnické fakultě (na druhý pokus mne tam přijali) jsem byl seznamován nejen s právními předpisy a jejich výkladem. Nevědomky jsem se již tehdy učil, jak učit na vysoké škole; poznával jsem také různou mentalitu pedagogů a studentů. $K$ době vlastního vysokoškolského studia jsem se častěji vracel, když jsem na něj vzpomínal již na brněnské fakultě se svými kolegy Urfusem, Vlčkem, Matesem a Turkem, také pražskými absolventy. Proto jsem se rozhodl, že i v tomto příspěvku zaznamenám svá „učednická léta“ na pražské právnické fakultě. Takové vyprávění příležitostně doplním výslovnými poznámkami o tom, jak doba vlastních vysokoškolských studií ovlivnila mé pozdější pedagogické působení na brněnské právnické fakultě. Snad z toho bude možné poznat moji „filozofii“" vysokoškolského učitele. Jako „vytknutí před závorku“ uvádím obecnější poznatek: Pedagog učí zejména svým příkladem, někdy i príkladem odstrašujícím.

Od prvních dnů studia na pražské fakultě mne zaujalo římské právo v brilantním podání tehdejšího odborného asistenta a pozdějšího docenta i profesora Jaromíra Kincla. Bylo to pro první setkání s platným právem, i když platným v jiné době. Jeho prostřednictvím nás Kincl učil právnickému myšlení. Při zkoušce jsem měl např́klad odlišit držbu od detence, což může být zkoušková otázka i ze současného občanského práva. Po létech jsem pak tvrdil a myslím si to dodnes, že pro pozdější praxi podnikového právníka mi na fakultě dalo nejvíc římské právo. Stále jsem přesvědčen, že mu v programu současné právnické fakulty náleží důležité místo.

Ř́mské právo bylo v indexu vedeno pod povšechnějším označením „obecné dějiny státu a práva“, kam patřily i jiné právní jevy ve starověku. Byl jsem zařazen do semináře, který vedl odborný asistent Stanislav Balík. Když na něj v prŕležitostném článku vzpomínal jeho syn stejného jména (současný advokát, čilý právní publicista i znalec právní historie), napsal, že otec se celý život řídil výrokem profesora Arnošta Weniga-Malovského: „Studenti maji na učiteli poznat, že má zájem o svioj obor a že ke nim má dobrý vžtah. "Neznám stručnější a výstižnější i stále platný požadavek na vysokoškolského učitele.

Členem katedry dějin byl i Josef Tureček, který dříve působil jako profesor církevního práva. V našem ročníku přednesl jedno téma z „římana“ (myslím, že šlo o římskoprávní pojetí „věci“) a dvě přednášky o kanonickém procesu. Mám výraznou vzpomínku na jeho hlasitý přednes, živou gestikulaci a „pochod“ po učebně.

V poválečném období nejvíc proslul spiskem „Právo, křivda, neprávo“, v němž odsoudil nacistické pojetí práva. Znalost této brožurky prý požadoval či oceňoval při každé zkoušce. Studenti mu pak z té brožury citovali několik vět a demonstrativně naznačovali, 
že jsou vlastníky oné knížečky, i když se většinou jednalo o svazek putovní. I po létech jsem si připomínal tuto historku a byl přece jen o něco zdrženlivější, když jsem studentům doporučoval vlastní publikace.

Rád si připomínám tehdejšího asistenta nebo snad již docenta a pozdějšího profesora Němečka, který nám v prvním ročníku přednášel politickou ekonomii. Vycházel v podstatě z Marxova Kapitálu a doporučoval či dokonce studentům ukládal studium př́mo z tohoto zdroje. Dostal jsem se k němu v knihovně, těžko dnes říct, zda ze studijní píle či zvědavosti. Ocenil jsem zejména stylistické umění autora a jeho odkazy na díla beletristická. Pamatuji si např́klad citát z Goetha, který měl charakterizovat mentalitu kapitalistovu: „Dvé duši mu v těle sídli a darmo se od sebe touži odtrhnouti. “Dnes Marxův Kapitál leckde v cizině znovu vychází a je dokonce „salonfähig“ v některých intelektuálských kruzích - i těch, které neprrísahají na Komunistický manifest. Marxův Kapitál se ovšem musí vykládat, a k tomu Němeček opatrně směřoval, jako jedna, nikoliv jediná možná, z koncepčních ekonomických teorií, která má určitou logickou strukturu.

$\mathrm{Na}$ fakultě jsme měli logiku jako samostatný předmět. Oblíbil jsem si ten obor a jeho dva učitele $z$ filozofické fakulty. $V$ indexu se mi při zkoušce čitelně podepsal Dr. Dušan Machovec, druhý se jmenoval - pokud se nepletu - Jauris. Přednášky byly převážně věnovány výrokové logice aristotelského ražení. Pamatuji si z nich př́klady následujícího typu: Z predpokladů jednak „Husa má dvě noby" a jednak „Sousedka má dvě noby “ logicky nevyplývá, ře sousedka je husa. Dvě přednáškové lekce byly věnovány matematické logice; tu jsem začínal chápat až po důkladném obrušování mozku. Dnes bych takovou myšlenkovou masáž doporučoval všem, kteří studují na právech zejména proto, že jim na gymnáziu „nevoněla“ matematika. Přednášky z logiky jsem si později připomínal, když jsem v právních sporech různého druhu vedl slovní i písemné souboje a uplatňoval např́klad argumentaci ad absurdum; od „většího k menšímu“ i jiné logické kategorie.

Základy marxismu-leninismu nás učil docela vlídně působící a usměvavý muž; myslím, nejsem si tím však jist, že to byl Stanislav Kučera. Dialektický zákon přeměny kvantity v novou kvalitu objasnil pomocí následujícího př́kladu: „Máte u sebe deset haléřu a chcete jet tramvají. Nemůžete, protože vaše peněžní zásoba není dostatečná $\mathrm{k}$ tomu, abyste zakoupil jízdenku v ceně jedné koruny; nemáte ani jízdenku předplatní.“ Pak následovala dramatická pauza a pedagog pokračoval: „Získáte dalších deset haléřu a chtěl byste jet tramvají. Opět nemůžete $z$ důvodů již uvedených." V př́kladu pak přidával po desetnících a prodlužoval dramatické pauzy. Končil téměř triumfálními slovy: „Měl jste devadesát haléřu a přibyl vám další desetník. Chcete jet tramvají a můžete jet tramvají, protože narůstající kvantita se dialektickým skokem změnila v novou kvalitu.“ Byl to prŕklad triviální, ale dobře pochopitelný. Později jsem ho použil a mírně ironizoval ve fejetonu. Tvrdil jsem tam, že narůstající kvantita nemusí vždy vést k nové kvalitě kladné. Jako př́klad jsem uváděl, že kráčíme směrem k propasti a se vzrůstajícím počtem kroků se k propasti prribližujeme. 
Učitelovy neobvyklé př́klady či výroky bývají vůbec zdrojem studentského a literárního humoru. Dějiny sovětského státu a práva učil tehdy na fakultě profesor Vladimír Procházka. Jeho přednášky nebyly zvlášt' zajímavé, i když on sám si zřejmě pochutnával na některých částech svého výkladu. Např́klad zdůrazňoval a i v ruštině uváděl, že předrevoluční ruská duma se rozešla poté, co velitel stráže námořník Železňakov prohlásil: „Karaul ustal, nado kančat’ - Stráž je unavena. Je třeba skončit.“ Můj kolega z ročníku Ivan Kulhánek (později autor povídek a epigramů v humoristických časopisech) se před zkouškou ze „sověta“ (tak jsme říkali oboru „Státní právo SSSR“) vsadil, že onen výrok uplatní, at' si vytáhne jakoukoliv otázku. A skutečně - měl pojednat o jakési záležitosti z třicátých let a odpověd’ zahájil větou: „Událost, která mi byla zadána jako otázka, je obloukem historické příčinné souvislosti spojena s výrokem, který v předrevoluční dumě pronesl velitel stráže, námořník Železňakov: ,Karaul ustal. Nado kančat'، “ Potom Ivan Kulhánek vyprávěl (i podle svědectví jeho kolegy na „potítku“) o rozchodu předrevoluční dumy a též o bezprostředně následujících událostech. Zkoušku úspěšně složil a vyhrál i sázku.

V takových a jim podobných případech může být zkoušející naivně samolibý, nahluchlý nebo se v nitru baví studentskou fintou. U profesora Procházky bych nevyloučil žádnou $z$ těchto variant. On totiž byl člověk se zajímavou minulostí a vůbec všestranný. Proslul překladem díla „Hrozny hněvu“ od Johna Steinbecka i spisku „Průvodce inteligentní ženy po socialismu a kapitalismu“, který napsal G. B. Shaw. Opakovaně jsem četl jeho vtipný překlad anglické detektivky od Dorothy Sayersové „Vražda potřebuje reklamu“, která vyšla již za první republiky a byla později znovu vydávána. Pomohla mně i některým mým studentům a soudcům pochopit praktiky, které se používají v reklamní branži. Semináře ze „sověta“ vedl v naší studijní skupině Stanislav Zdobinský. Vzpomínám si, že nám zadal i obecněji pojatý úkol. Měli jsme napsat, k čemu je užitečné, když se návrhy zákonů předkládají k veřejné diskusi. Odpověděl jsem „státotvorně“, že občané, kteři se mohli $\mathrm{k}$ právnímu předpisu předem vyjádřit, budou jeho znění spíše respektovat. „Zdobiňák“, jak jsme mu ř́rkali, mne pochválil za takovou myšlenku a dokonce si ji poznamenal. Později jsem k ní byl sám skeptičtější a napsal, že takové diskuse mohou pro někoho být i přípravou na prř́ští obcházení zákona.

Teorii státu a práva přednášel v našem ročníku profesor Radim N. Foustka. Za katedrou působil pro někoho nevýrazně, pro jiné až černokněžnicky. Spolu se svým asistentem Vladimírem Veverkou napsali brožuru „O protilidové politice Masaryka a Beneše“ (tak nějak se jmenovala), ze které jsme měli studovat. Když jsem ji doma předvedl otci, jen si povzdychnul: „To je ale úpadek.“ Na semináře s Vladimírem Veverkou a jejich obsah si vůbec nepamatuji.

Rád a vděčně vzpomínám na výuku francouzštiny a jejího lektora doktora Pravdu. Svoji úlohu bral opravdově, prostě „nomen omen“. Dělalo mu vyloženě potěšení, když nám vysvětloval tu či onu jemnůstku franštiny a my ji chápali. Doporučoval nám každý z nových a tehdy ještě nedabovaných francouzských filmů, v nichž vystupoval např́íklad 
Jean Marais, Gérard Philippe (s ním jsem Praze viděl i divadelní představenî), Yves Montand (navštívil jsem také jeho koncert v Lucerně, podobně jako vystoupení zpěvačky Lucienne Boyer). Z počínání doktora Pravdy jsem si později bral prríklad a svým studentům jsem doporučoval knihy, divadelní představení či filmy, jež poněkud souvisely s přednášenou látkou.

Při výuce ruštiny jsem se řídil názorem otce, který rád opakoval, uplatňoval a i na ruštinu vztahoval Masarykovo: „Kolik jazyků znáš, tolikrát jsi člověkem.“V našem kroužku na fakultě učila ruštinu paní v létech, Roubíčková se jmenovala. I ona studentům doporučila, aby shlédli představeni ruského souboru, který v tehdejším Realistickém divadle hostoval s Gogolovým „Revizorem“. Takovému návrhu jsem s chutí vyhověl, o představení jsem pak v semináři vyprávěl a získal tak sympatie lektorky Roubíčkové. O jedné mé písemné práci řekla, že jsou v ní sice gramatické chyby, ale přece jen se to ruštině poněkud podobá. Taková „podmíněná pochvala“ mne docela potěšila a podnítila ke studijnímu úsilí. Cosi podobného jsem občas použil i v seminářích z hospodářského práva.

Pokud jde o druhý ročník mého právnického studia, dobře si vzpomínám na semináře z hmotného trestního práva, které vedl doktor Dolenský. Byl to muž drobnější postavy a jeho zjev přiléhavě vyjadřovala přezdívka „,̌ertík“. Ve výuce používal výstižné a dobře pochopitelné i zapamatovatelné praktické př́klady. Jako omezování osobní svobody uvedl situaci, za níž vylezeme po žebříku na vysoký ovocný strom a někdo nám pak žebřík odejme. Z takových a jim podobných prŕikladů jsem si sám bral prríklad ve své přednáškové činnosti.

Rázovitou postavou na katedře tělesné výchovy byl asistent Zdvíhal, člověk chlapáckého zjevu a občas autor nekonvenčních výroků. Měl nás také na zimním výcvikovém kursu, který jsem považoval a dosud pokládám za významnou součást vysokoškolského vzdělání. Zdvíhal nás totiž proháněl nejen na sněžných pláních. Při večerním soutěžně pojatém programu dával „zabrat“ i našim mozkům. Pamatuji si na vcelku nevinnou hru, při níž jedna ze soutěžících skupin měla pomocí pantomimy předvést určitý slovní text; skupina druhá se pak snažila odhalit znění tohoto textu. Jeden ze zvlášt’ náročných slovních úkolů zněl: „Sivý mník zamrcasil př́idatným pazdírkem. “ Dodnes nepochopím, jak se taková slova dala naznačit pohybovou akcí a že byla nakonec identifikována.

V programu druhého ročníku studia jsme měli také státní právo ČSR, které učil Ján Gronský. Sám práva nevystudoval; absolvoval Vysokou školu politickou a sociální, která vznikla po roce 1945 a po únoru 1948 byla zrušena. Oprávněnost svého působení na právnické fakultě různě odůvodňoval. Poukazoval především na skutečnost, že později získal vědeckou hodnost kandidáta právních věd. Svưj pedagogický úkol nespatřoval v tom, aby uváděl kompetence těch či oněch státních orgánů. Chtěl rozsévat myšlenky. Jako politickou či dokonce státovědní kategorii uváděl a vysvětloval pojem ,jánabráchysmus“. 
Ján Gronský byl rozhodně zajímavá, barvitá osobnost v několikerém významu těch slov. Zřejmě i proto jsem se v roce 1956 přihlásil do jeho výběrového semináře či spíš debatního kroužku. Neřešili jsme tam právní problémy; Gronský jako člověk zkušený i událostmi doby zkoušený rád rozdával obecnější poznatky a rady do života. Např́íklad nám nezralým klukům doporučoval, abychom si životní partnerku nehledali mezi děvčaty zvlášt' půvabnými. Poněkud sofistikovanější podobu takových rad jsem př́ležitostně uplatnil při výuce práva proti nekalé soutěži, když jsem uvažoval o soutěžení na seznamovacím trhu.

Když v roce 1956 začínalo politické vření v Mad’arsku, Ján Gronský jednou spíš mimochodem řekl, že náš výběrový seminář či naše debatní skupinka je vlastně takový „Petöfiho kroužek“. Byla to charakteristika nevýstižná, žádné zvlášt’ revoluční, pobuřující a protirežimní debaty jsme v jeho kanceláři nevedli. Když pak mad’arské události ukončil zásah sovětů, měl prý Gronský na fakultě tvrdit, že ve svém výběrovém semináři podchytil a správně orientoval studenty nevyzrálého politického profilu. Vưči Gronskému jsem tehdy zatrpkl. Až později jsem si uvědomil, že dodatečnou charakteristikou onoho výběrového semináře či Petöfiho kroužku chránil nejen sebe, ale i nás studenty.

I v druhém ročníku jsem se setkával se Stanislavem Balíkem, který v naší seminární skupině vedl předmět nazvaný „Obecné dějiny státu a práva - kapitalistický řád“. Této disciplíně jsme říkali „,velké dějiny“ a dalo se to chápat hned ve dvojím významu toho slova. Skripta připomínala neskutečně rozsáhlé „skladiště“ údajů, které si nikdo nedokázal zapamatovat. Zkouškové nároky však byly rozumné a nikdy jsem neměl dojem, že by šlo o „Taxisův př́kop“v rámci studia. Katedra navíc vydala svého druhu „,ćítanku“, v níž se nacházely významné dokumenty z právní historie; to vše v originálním znění i v českém překladu. S gustem jsem tam četl např́klad úryvky $z$ francouzského občanského zákoníku (Code Napoléon); chápal jsem pak spisovatele Stendhala, který řekl, že četba tohoto zákonodárného díla mu poskytla výraznější estetický požitek než většina děl krásné literatury. Na francouzský občanský zákoník a jeho obecná ustanovení o právní odpovědnosti jsem pak po létech poukazoval, když jsem se zabýval odpovědností za nekalou soutěž.

Z českých právních dějin jsem si pamatoval především zvláštní historické výrazy, které v přednáškách používal a při zkoušce vyžadoval profesor Vaněček. O jakémsi společenství našich dávnějších předků například říkal: „Oni žijí o jednom chlebě, oni chlebi““. Vaněčkovy přednášky byly málo navštěvované a při jejich zahájení nás občas vítal slovy: „Hle, houfec mých věrných.“ Nezdálo se však, že by profesor Vaněček sankcionoval neúčast na přednáškách. Možná se nechtěl podobat svému předchůdci v oboru, profesoru Theodoru Saturníkovi, který prý při zkouškách rád kladl otázku, co je to „,vechno“. Někteří studenti (navedení staršími kolegy) se snažili $\mathrm{k}$ tomuto pojmu přiřadit cosi z české právní minulosti. Podle jedněch to měl být znak důstojenství, jaký př́slušel stařešinovi rodu. Podle druhých pak dědický podíl druhorozeného syna. Profesor Saturník 
nechával zkoušence bájit a pak prohlásil. „Nikoliv, je to překlep v poznámce pod čarou na straně té a té mé učebnice. Správně tam mělo být napsáno ,všechno'. Věděl byste to, kdybyste byl býval navštěvoval mé přednášky.“

Profesor Vaněček byl mimo jiné pověstný tím, že do výuky přicházel později a dřiv z ní odcházel. Vždy to vysvětloval jinými důležitými úkoly ve vyšším mezinárodním, státním či alespoň celouniverzitním zájmu. Šlo také o instruktivní lekce pro praktický život, v němž často musí být vysvětlován ten či onen druh nedochvilnosti. Vypráví se, že jednou předčasně ukončil přednášku s tím, že musí jít jako promotor do Karolina. Hlučný odchod rozradostněného houfce posluchačů zaznamenal děkan fakulty a pobouřeně se zeptal, co že se to děje. Dostalo se mu následující odpovědi: „Profesor Vaněček ukončil dřív přednášku, protože musel jít pro motor do Karlína.“

Jiná historka svědčí o prestižní povaze profesora Vaněčka, člena korespondenta ČSAV. Když se na něj obrátil písemně Karol Laco, profesor bratislavské právnické fakulty, přehlédl překlep, kterého se dopustila písařka, jež adresáta označila za člena korespondenta ČSAD. Profesor Vaněček si překlepu povšimnul, list vrátil odesilateli a ke zkratce „Československé autobusové dopravy“ prripsal: „Nepřijímám.“ Sebevědomí dával najevo i jindy a dost tvrdě. Napsal například dílo o českých právnících z minulých období a byl za něj kritizován. Ideologická pochybení mu vytýkal zejména docent Ferdinand Boura, tehdejší děkan. Když se Boura ucházel o hodnost akademika či snad člena korespondenta a neuspěl, profesor Vaněček prý na chodbě fakulty halasně oslovil uklízečku: „Tak nám zabili Ferdinanda, paní Müllerová.“V jiné verzi se vypráví, že takto profesor Vaněček komentoval předčasné úmrtí docenta Boury. Smuteční řečník na Bourově pohřbu měl pak prohlásit, že nepř́ejícnost k zemřelému šla až za hrob.

Již z druhého ročníku studia na pražské právnické fakultě jsem si tak přinesl a v pozdějších létech si opakovaně potvrdil poznatek, že i na intelektuálních pracovištích (a možná právě na nich) se ve značné míře pěstuje „drbárna“, pokud tomu nechceme zjemněle říkat aplikovaná psychologie či „,fakultní folklór“. Myslím, že to platí i pro brněnskou právnickou fakultu, byt' v podobě podstatně umírněné.

Ve třetím ročníku studia jsme měli předměty, jimiž jsem byl velmi zaujat. V̌̌dy jsem se vysloveně těšil na přednášky profesora Viktora Knappa. Učil nás smluvnímu občanskému právu, jeho výklad byl zajímavý, srozumitelný a zároveň teoreticky podnětný. Vycházel z knihy o splnění závazků a jiných způsobech jejich zániku, kterou tehdy napsal. Po tomto spisu jsem pak častěji sáhnul jak v podnikové praxi, tak v době, kdy jsem sám přednášel a psal o smlouvách. Velice živě si naprŕḱlad pamatuji, jak nám profesor Knapp vysvětloval rozdíl mezi právními domněnkami a právní fikcí a uváděl, že právní domněnky vyjadřují stavy, které jsou v životě obvyklé a v konkrétní situaci dosti pravděpodobné, i když ne zcela jisté. Na míre té pravděpodobnosti pak obvykle 
záleží, zda se jedná o právní domněnky, které lze vyvrátit důkazem opaku (například domněnka, že otcem dítěte je manžel matky), nebo nevyvratitelné. Právní fikce je pak stav, který ve skutečnosti neexistuje, ale je právem uměle konstruován, aby právo vůbec mohlo fungovat, „aby práva šla“. Dá se vyjádřit slovy: „Jako by to bylo, i když to není.“ Nejsem si jist, zda již od Knappa jsem převzal př́klad poněkud krkolomné či zbytečné právní fikce, který jsem pak v přednáškách používal. (Starší lázeňský rád obsahoval ustanovení: „Do ženského oddělení lázní je dovolen přístup pouze ženám. Pro účely tohoto řádu je plavčík považován za ženu.') Později, jako prŕklad podobný právní fikci, jsem uváděl sdělení některých katolických farností, že velká mše zpívaná se koná v sobotu s nedělní platností.

Příští manželka profesora Knappa, tehdy ještě doktorka Doláková, měla u nás dvě přednášky a zabývala se v nich teorií právní odpovědnosti. Přednášela přehledně, i když ne tak suverénně jako Viktor Knapp. S několika jeho názory nesouhlasila a zdůrazňovala originalitu svého vědeckého přesvědčení. Fakultní zlomyslníci ř́kali, že profesor Knapp je velmi myšlenkově potentní a dovede produkovat různá i protikladná stanoviska. Dokonce prý dokáže polemizovat se sebou samým, což činí prostřednictvím své životní partnerky. Myslím, že to vưči ní nebylo úplně spravedlivé.

„Knapka“, jak se jí později říkalo, dovedla být i originálně vtipná. Když byly v občanském zákoníku upraveny takzvané konkrétní smluvní typy a nahradily obecnější smlouvu o dílo, rríkala i napsala: „Je nyní sporné, zda ostř́hání hlavy u holiče je ,oprava a úprava věci‘, nebo ,zhotovení věci na zakázku“." Sám jsem tuto myšlenku použil ve svých přednáškách a odkázal na původní autorku.

Z tehdy mladší generace civilistů nás učil asistent a pozdější profesor Jiří Švestka. Byl jsem zaujat jeho výkladem o náhradě škody, který mi připomínal způsob, jakým psal profesor Jan Krčmář, přední civilista z předchozí generace. Uvědomil jsem si to, když jsem si četl v knížce „Čtení o psaní, bydlení a jiném činění znovu vydané v začátcích mého vysokoškolského studia. V tomto souboru parodií autor Václav Lacina, (absolvent práv, soudce a literát), uvádí, jak by různí autoři pojednali dětskou říkánku: „Šel dráteník po silnici / selkea na néj volala, / aby ji šel zadrátovat / hrnec s dvouma uchama." Profesor Jan Krčmář by prý v úvaze právní napsal: U posuzovanébo přpadu musime roz̧eznávati tru složky: 1. Co selka cinila, 2. proč take činila, 3. co z toho vzešlo.

Ad 1. Jak patrno z. drubébo verše in fine, vyšla od selky iniciativa (arg. „na nèj volala“ a contr. „na ni volal"), aby došlo ke smlouvé o dílo mezi selkou jako offerentkou a dráteníkem jako oblátem. Text prvých dvou veršu vede na to, že tu šlo o nabidku podle \ 861 o.z., tedy nikoliv o veřjnép prislíbeni podle $\int 860$ 0.\%:

Lacinův, respektive jako by Krčmářưv text ještě pokračuje na celé stránce, ale již na této ukázce se dá přibližně demonstrovat, jakým způsobem tehdy přednášel i psal Jiř́ Švestka a učil nás tak přesnému právnickému vyjadřování. 
V třetím ročníku studia se také přednášelo a zkoušelo trestní právo hmotné. Naučil jsem se $z$ něj podstatné věci, jako byly např́klad formy zavinění - druhy úmyslu a nedbalosti. Výborně přednášel Boris Vybíral, který, žel, za několik let předčasně zemřel. Koncepčními otázkami trestního práva se zabýval vedoucí katedry Vladimír Solnař. Patřil k výrazným osobnostem pedagogického sboru a proslul i jako náročný examinátor. Vyžadoval nejen znalosti, ale i určitý respekt k samotné zkoušce. Vypráví se, že nedbale oblečenému studentovi řekl: „Přrišel jste oblečen jako na sportovní mač. Uvidíme, zda budete vítězem.“ Dnes už si nepamatuji, kdo mne z trestního práva hmotného zkoušel, podpis v indexu je nerozluštitelný. V každém případě jsem přišel ke zkoušce řádně oblečen (v poděděném a přešitém obleku po dědečkovi, který si ho původně pořídil k diamantové svatbě) a snad i to se podílelo na zdárném výsledku zkoušky.

Na vlastní důstojný vzhled a chování dbal nejen profesor Solnař ale i jeho podřízený, pozdější profesor Růžek, který nás učil a zkoušel z trestního práva procesního. Po létech jsme vedle sebe seděli na právnické konferenci v Bratislavě a on tehdy s pohoršením poznamenal, že jeden z českých přednášejících přišel oblečený až příliš ležérně.

Profesora Vladimíra Solnaře si vybavuji také jako učitele poněkud odtažitého v jednání se studenty. Možná ho nejlépe charakterizuje výrok, který v době mých studií pronesl na pedagogické konferenci učitelů právnické fakult. Řekl tehdy: „Učitel mưře prí výuce ř́ci vtip, ale pr̆ tom nesmí zesměsnit trù věci: studenta, svịj predmèt a sebe sama. "1

Rád souhlasím s tím, že bychom neměli studenty zesměšňovat. Zároveň však vím, že i Solnařův výrok v celé jeho šíri neplatí pro anglického profesora. Ten si má dobírat svůj obor i sám sebe; takový př́stup je mi bližší. Tak si prý počínal i předválečný profesor finančního práva na pražské právnické fakultě, který zahajoval přednášky větou: „Orangutani by mohli mluvit, ale nečiní tak, aby nemuseli platit daně.“ Méně originální byl náš učitel finančního práva, bývalý náměstek ministra financí a pozdější profesor Bedřich Spáčil. Z jeho výuky jsem si odnesl prredevším obecnější poznatek pro svou pozdější pedagogickou činnost. Je zbytečné na fakultě vyučovat a pak zejména zkoušet aktuální sazby daní a tomu podobné údaje, které se budou v profesionálním i občanském životě absolventů ještě mnohokráte měnit. $K$ takovému přístupu jsem se snažil vést, ostatně ne vždy úspěšně, kolegu z brněnské fakulty, který na katedře mnou vedené učil finanční právo.

$\mathrm{V}$ třetím ročníku právnického studia mám v indexu uveden i dialektický a historický materialismus. Jméno přednášejícího si nevybavuji, jeho zjev bych označil za vizionářský. Přednášku zahájil citátem z Dostojevského: „Pokoř se, hrdý člověče!“ a tuto myšlenku dlouze rozebíral velice vzrušeným způsobem mluvy. Nebylo mi tehdy jasné, co nám hodlal sdělit o Dostojevském, Rusku jeho doby či ohledně naší tehdejší současnosti.

1 Citováno dle KUČERA, S. Sine ira et studio (Právnická fakulta vážně i vesele). In: Memorabilia iuridica, sv. 8. Praha: Univerzita Karlova, Právnická fakulta, 2016, s. 15. 
Učení o dialektickém a historickém materialismu ta přednáška připomínala jen na základě dialektického zákona o všeobecné souvislosti jevů. Přednášejícím jsem však byl zaujat a pokynem Dostojevského jsem se párkrát v životě řídil, někdy ke své škodě, jindy snad ku prospěchu. Za pár let jsem se doslechl, že muž, který učil marxismus prostřednictvím Dostojevského, spáchal sebevraždu.

K bojovnějšímu chování nás hodlal vést učitel tělesné výchovy Sláma. Býval členem reprezentačního mužstva $v$ rugby a zlákal řadu studentů z různých ročníků, včetně mne, abychom se tomuto sportu věnovali a hráli ho i závodně. Z družstva si vybavuji zejména Vojtěcha Cepla, kolegu z nižšího ročníku a pozdějšího učitele i profesora na pražské právnické fakultě. Zvlášt' si pamatuji, jak radostně hlaholil „meleme, meleme“, když jsme vytvářeli jednu z pozic té hry, zvanou mlýn. Také opakovaně prohlašoval: „Gorodky jsme měli pěstovat, gorodky. To by bylo podpory a uznání.“ Prostě jeden z výroků, které jsou těžko napadnutelné, protože se dají různě vykládat.

V této souvislosti si připomínám i zemědělskou brigádu, kterou jsme snad měli před začátkem třetího ročníku nebo čtvrtého ročníku. Dnes již nevím, co jsme sklízeli a kde přesně jsme byli. Velice dobře si však pamatuji, že jsme pro místní obyvatele uspořádali estrádu, kterou jsem konferoval a snad i tím se prripravoval na budoucí pedagogické působení. Skupinka kolegů a kolegyň s hudebním sluchem zpívala parodii na tehdy oblíbený šlágr „Cím víc tě mám rád, tím víc je mých strasti“. Pěli: „Mám rád ementál, ten sýr, co má díry. Mám rád ementál, ten sýr mezi sýry. Mám rád i žervé, ten mi nervy nerve. A tím pojídáním sýrü, síli naše cesta vpred, silí jím i celý tábor míru, vybudujem lepši svět. "Dozírající pedagog, pokud se nemýlím, byl to tehdy Dragutin Pelikán, neměl námitky proti takovému textu ani proti jinému studentskému dovádění.

Ve třetím ročníku fakulty nám Ján Gronský přednášel předmět, který mám v indexu zapsán jako „státní právo lid. dem. zemí. Tento pojem pojal dost široce a mezi lidově demokratické země zařadil i Maovu Čínu. Dozvídali jsme se leccos o Všečínském shromáždění lidových zástupců, o počtu jeho členů a složení předsednictva a také o jiných subtilitách čínského ústavního systému. Zdálo se, že si Gronský na informacích o čínských právních poměrech zvlášt' pochutnával, alespoň já jsem si to jako jediné zapamatoval z celého kursu. Kdybych byl jedovatý i osobní, usoudil bych, že šlo o informace perspektivně užitečné.

Další oborem bylo správní právo, o kterém jeho učitel a pozdější děkan fakulty s francouzsky znějícím jménem Delong říkal: „Správní právo je právo správné.“ Nevím, co touto charakteristikou mínil, onen obor v tehdejším fakultním podání mne příliš nezaujal. Jeho zvláštní část byla totiž roztříštěna do množství nejrůznějších dílčích úprav. Dobře to později naznačila následující historka. Kdosi prý požadoval, aby se na fakultě učilo dopravní právo jako zvláštní disciplína. Profesor správního práva Pavel Levit k takovému návrhu poznamenal: „To je výborná myšlenka. Jen bychom měli být důslední a zrrídit zvláštní 
právní obor pro dopravu tam a jiný pro dopravu zpět.“ Potvrdil, že zábavní mohou být i učitelé z oboru zdánlivě suchého.

Z třetího ročníku studia si výrazněji vzpomínám také na rodinné právo. Hlavní představitelkou oboru byla Senta Radvanová, učitelka zajímavého krestního jména i zjevu, která měla pověst přijatelné zkoušející. Z přednášek jsem si důkladněji pamatoval jen výklad o domněnkách otcovství. Zřejmě jsem usoudil, že těmito poznatky budu dostatečně vybaven pro zkoušku i pro chystaný týdenní pobyt v Krkonoších, kam jsem odjel se svou tehdejší dívkou a s lyžemi. Do hor jsem si vzal i učební pomůcku z rodinného práva; výjimečně jsem do ní nahlížel a vyvolal tak mrzutou reakci u partnerky.

Sám jsem zneklidněl až v okamžiku, kdy jsem zjistil, že mne nebude zkoušet Senta Radvanová, ale obvykle náročnější doktorka Marta Doláková, pozdější profesorka Knappová. Jako otázku jsem si „,vytáhnul“ jakousi teoretickou jemnůstku, která zajímala spíš examinátorku než mne. O zdání vědecké hloubky jsem usiloval tím, že jsem mluvil zvlášt' učeně a používal latinské termíny, ne vždy ve správném významu. Zkoušející nad tím podrážděně odfrkávala a já si párkrát pomyslel, že mne musí vyhodit. Nakonec z toho byla „dvojka“. Až nepřiměřeně mne mrzela, i když neovlivnila prospěchové stipendium. Měla však obecnější efekty pedagogického rázu. Poznal jsem, že dávat přednost potěšení před povinností, může poškodit nejen plnění povinnosti, ale i kazit samo potěšení. Jako učitel práv jsem pak byl při zkouškách nevrlý na studenty, kteři se snažili pseudovědecky blábolit.

Po nějakém čase sebevýčitek jsem byl s vlastním zkouškovým výsledkem smíren hlavně proto, že kolegové z ročníku mne začali „více brát“. Takto poučen jsem v letním semestru třetího ročníku celkem stoicky přijal stejnou „horší“ známku i ze správního práva.

Své pocity ze zkoušek na pražské fakultě jsem si připomínal, když jsem se sám stal examinátorem. V prvním období svého pedagogického působení jsem se někdy v noci budil a trápil se představou, že jsem v tom či onom prrípadu nebyl dostatečně spravedlivý. $\mathrm{Na}$ některé z takových pochyb vzpomínám dodnes. Zkoušel jsem dvojčata a jednomu z těch kluků dal ,jedničku“ a druhému možná dost př́isně nadělil „dvojku“. Jeho smutný pohled mne pak pronásledoval v oněch nočních okamžicích. Dokázal jsem si dodatečně vysvětlit pocity takto „postiženého“; mám totiž bratry dvojčata. Brzy však jsem při svém učitelském a zkouškovém pưsobení dospěl k jisté profesionální otrlosti. Raněné city těch, kdo se cítili na lepší známku, jsem občas preventivně tišil úvodním prohlášením: „Absolutní spravedlnost není z tohoto světa.“ Někdy jsem oficiální klasifikační stupeň zjemnil dodatečnými slovy - např́klad ve formulaci: „Máte dobrou, hodnou svého jména."

Významným oborem přednášeným a zkoušeným ve čtvrtém ročníku bylo občanské právo procesní. Tuto druhou větev civilistiky reprezentoval profesor František Štajgr, jeden čas 
i děkan fakulty. Vnímal jsem ho jako jedince vždy pečlivě oblečeného a působícího velmi seriózně, i když poněkud zasmušile. Mluvil také ztichlým hlasem. Na jeho přednáškách v největší z poslucháren na pražské fakultě se nás scházelo něco kolem deseti posluchačů. Nebylo mi samotnému jasné, proč na přednášky chodím, jestli z píle a pomyšlení na prospěchové stipendium, ze zvyku nebo z úcty či dokonce z jakéhosi soucitu k profesoru Štajgrovi. Ten se ale účastí či neúčastí na svých přednáškách nijak nevzrušoval, alespoň ne zjevně. V̌̌dy přišel v přesnou dobu a ve stanovený čas přednášku skončil. Abych byl spravedlivý, neplatilo pro něj, co se ř́kalo o profesoru z jiné generace, který prý přednášku uzavřel třeba v polovině věty a větu dokončil na začátku příští př́ednášky.

Za podstatné pro právnické vzdělání studentů jsem považoval skutečnost, že profesor Štajgr napsal důkladnou a přehlednou učebnici občanského procesního práva. Z ní jsme se mohli naučit základy tohoto oboru teoreticky náročného a prakticky užitečného. Ostatně z pedagogické teorie jsem se poučil, že přednášky jsou nejméně účinný způsob předávání informací. Postačí, když si z nich posluchači odnesou některé klíčové momenty (napríklad v podobě zajímavých př́kladů) a systematické poznatky naleznou v dobré učebnici.

Profesor Štajgr měl také jako vedoucí katedry kvalitně obsazený obor. Pozdější profesor a děkan Plundr přednášel i zkoušel předmět „organizace soudů a prokuratury“. Zvláštní vzpomínky na jeho pedagogické působení nemám, zůstal mi jen pocit, že šlo o solidního vysokoškolského učitele. Semináře vedli i někteří bývalí či tehdy i současní soudci (jejich poznatky z pracovního působení byly velmi podnětné) a z mladších učitelů Zdeněk Češka. Ten přednesl pečlivě připravený výklad o tehdejším arbitrážním řízení, který jsem ocenil při pozdější činnosti podnikového právníka. $\mathrm{K}$ studentům se choval vstř́ícně a zároveň s povinným akademickým odstupem.

Po odchodu z akademického světa se úspěšně uplatnil v advokacii. Jeho důstojné profesionální chování jsem po létech ocenil, když v rozhodčím řízení zastupoval spornou stranu a sám jsem byl jedním z rozhodců.

Od čtvrtého ročníku studia se mi také naskytla další vzdělávací prríležitost. Na fakultě tehdy byla zrrízena mezinárodněprávní specializace, která poskytovala cosi navíc k předmětům běžného právnického studia. Zájemci o rozšířené vzdělání museli složit vstupní zkoušku. $\mathrm{Na}$ tu jsem se o prázdninách připravoval tak vehementně, až mě otec krotil slovy: „Už toho nech, když budou chtít, tak tě přijmou, a když nebudou chtít, nepřijmou." Opět jednou měl pravdu. Zkouška netrvala dlouho a připadala mi jako formální.

Předmět zajišt'ovala katedra mezinárodního práva. Na mladší učitele, tehdy ještě asistenty této katedry, si většinou vzpomínám spís jen podle jejich jmen či přezdívek. Odborník na mořské právo Miroslav Potočný, který na fakultu přešel z Brna, byl posluchači titulován jako „Mořský, říční, potočný“; Čestmíru Čepelkovi se říkalo Gilletti. K studentům 
a studentkám měl tehdy nejblíž Josef Pokštefl, který zůstal, jestli si dobře vzpomínám, bez přezdívky stejně jako asistent Michael Milde. Ten učil mezinárodní právo soukromé a jako všichni dobři kantoři občas překročil hranice svého oboru. Pamatuji si, jak nám vykládal př́pad z americké právní praxe. Automobilista, který porušil dopravní předpisy, mohl zranit poměrně známou filmovou herečku. Fyzickou újmu jí nezpůsobil, ona však žalovala pro nehmotnou újmu, kterou vyjádřila jako „ztrátu úsměvu“. Milde pak výrazně slovy i gesty předvedl spor advokátů o to, zda herečka měla, či nikdy neměla zvláštní a jen pro ni charakteristický úsměv, zda o takový úsměv byla, či nebyla připravena vinou řidiče, zda to omezilo nebo naopak rozšíríilo její pracovní a výdělkové přiležitosti. Žalující straně pak byla přiznána náhrada nehmotné újmy, byt' v sumě menší, než jaké se herečka dožadovala. Nebylo tehdy zřejmé, zda Milde nám takto chtěl naznačit podivnosti amerického soudnictví či rozvinout naše právnické myšlení, poprrípadě předvést všestrannost svých talentů. Později emigroval, žil v Kanadě, stal se tam oblíbeným vysokoškolským profesorem a významným funkcionářem $\mathrm{v}$ mezinárodní organizaci pro civilní letectví. Jeho př́klad se „ztrátou úsměvu“ jsem pak použil ve vlastní autorské i pedagogické činnosti.

Oba profesoři na katedře mezinárodního práva byli velmi inspirativní jedinci. Mezinárodní právo soukromé učil Rudolf Bystrický, bývalý velvyslanec ve Velké Británii, muž elegantní svým zjevem, ústním projevem i gestikulací. Svůj obor označil za cosi jako „právnické šachy“ a jejich pravidla vykládal systematicky, i když s rozumným zjednodušením. Z jiného „kantorského těsta“ byl profesor mezinárodního práva veřejného Vladimír Outrata, bývalý velvyslanec ve Spojených státech. Zjev měl méně uhlazený a řekl bych, že byl spíš umělecky založený. Takový dojem jsem si potvrdil, když jsem mu jednou měl cosi z knihovny přinést do jeho bytu a ohromila mne tam spousta knih porůznu rozložených. (Mimochodem jeho manželka překládala z angličtiny beletrii, myslím že především detektivky.)

Způsob, jakým profesor Outrata konal přednášky a vedl semináře ve speciálním kursu, byl nepř́liš systematický. Byl však spoluautorem přehledné učebnice a také jeho př́ležitostné články (pamatuji si na stat' o právní problematice Suezského průplavu) byly $z$ více ohledů podnětné. $Z$ jeho semináře o diplomatické a konzulární praxi (to byla součást speciálního výukového programu) si pamatuji několik postřehů a prríhod. Byly mi užitečné v osobním i profesionálním životě, byt' jsem se diplomacii nikdy nevěnoval. Profesor Outrata nám např́klad vysvětloval tř́i základní diplomatovy úkoly - chránit (rozuměj chránit zájmy vlastního státu a jeho občanů), vyjednávat a pozorovat. Jak sporný může být úkol posléze uvedený, naznačil následujícím př́kladem: „Představte si, že diplomat jde po ulici ve státě svého poslání a na chodníku náhodně spatří jakýsi dokument. Zvedne ho a zjistí, že je označen jako prrísně tajný. Neodvrátí pak od něj zrak, neřekne si: ,To přece nemohu.' Zjistí jeho obsah a pokud jej vyhodnotí jako relevantní pro vlastní zemi, diskrétně o něm informuje své ministerstvo zahraničí.“ 
Profesor Outrata nám také vyprávěl, jak nezkušený pracovník diplomatického protokolu plánoval program pro zahraničního státníka a opomněl, že i vynikající osobnosti veřejného zájmu mají běžné fyziologické potřeby. Mohl tak státníkovi způsobit nemalé komplikace; možná i potíže zdravotní či dokonce smrt. Pro každou veřejně činnou osobu a pro budoucí učitele zvlášt' byla poučná další Outratova historka. Při státní recepci prý diplomat použil toaletu a teprve u stolu si povšimnul, že nechal otevřený poklopec u kalhot. Snažil se ho pak dodatečně zapnout pod deskou stolu. Při takové manipulaci si přiskřípnul kravatu do zipu od kalhot. Když pak měl povstat k př́ípitku, učinil to ve sklopené poloze. Na př́kladech profesora Outraty jsem si zvlášt' uvědomil, že dobrý učitel přednáší a píše nejen o svém speciálním oboru, ale jeho prostřednictvím do určité míry učí o životě vůbec.

Jisté obecnější poučení mi přinesla i další historka, kterou znám z doslechu. Profesor Outrata se jednou vyrrítil z pracovny asistentů, mezi prsty napřažené ruky držel součást intimního dámského prádla a zvolal: „Toto jsem nalezl mezi prameny mezinárodního práva veřejného.“ Prý měl i dodat: „Jistá souvislost by tu ovšem byla.“ I o této epizodě, součásti již zmiňovaného fakultní folklóru, možná platí, že vyprávěné historky nemusejí být ve všem všudy pravdivé, hlavně aby byly zajímavé.

Ze seminářů s profesorem Outratou jsem si odnesl poučení mnohem závažnější a také prakticky potřebná. Myslím tím především jeho postřeh, že malé státy nemohou samy o sobě vyhlásit neutralitu, pokud ta není garantována velmocemi. Z obecnějších myšlenek profesora Outraty si pamatuji i na jeho zdůrazněný a opakovaně použitý výrok: „Př́lišná horlivost škodí.“ Někdy jsem se jím měl více řídit.

Kantorsky horlivý nebyl profesor Vladimír Kadlec, později jeden z dočasných ministrů školství. V indexu mám od něj zápočet z předmětu mezinárodní obchod. Určitě vím, že v naší skupince „mezinárodníkư“ měl jedinou přednášku či seminář. Povídal si s námi mimo mnohé jiné i o problematice směnných kursů. V této souvislosti se zmínil o tom, že měl kdysi možnost přivézt si ze zahraničního pobytu nepřihlášené valuty a vzhledem k tehdejší kurzové relaci uskutečnit ekonomicky velmi výhodnou transakci. Uvažoval prý, že bankovky převeze $\mathrm{v}$ botách, ale nakonec se mu takový postup jevil jako př́liš riskantní a od svého úmyslu prý upustil. Dodnes nevím, zda to bylo poučení návodné, či odstrašující.

Téměř nic si nepamatuji ze zemědělskodružstevního práva, které nás učil profesor Valer Fábry, také na fakultu odsunutý z vyšší státní funkce. Předával nám mimo jiné pomíjivé poznatky o tom, jaká byla v jednotných zemědělských družstvech př́pustná výměra záhumenků a kolik domácího zvířectva mohl záhumenkář chovat. Možná šlo o něco podobného, jako jsou balastní látky v jídlech, které umožňují lépe strávit výživnější součásti pokrmů. 
Z učitelů ve čtvrtém ročníku studia si vybavuji také tehdejšího asistenta Igora Tomeše z katedry pracovního práva, který zajímavě vedl semináře a s úspěchem se snažil o přátelský vztah ke studentům. O vedoucím jeho katedry šírili studenti i někteří učitelé veršovánku: „Docent Witz neví nic.“ Dodatečně se mi taková charakteristika nezdá úplně spravedlivá. Jak už je to běžné ve verších, možná se uplatnil zvláštní druh obsahové poetické licence: skutečnost byla přizpơsobena tak, aby se vyhovělo požadavkům rýmu.

V pátém ročníku bylo velice zajímavé i poučné státní právo kapitalistických zemí. Přednášel a skripta napsal Vladimír Klokočka, pozdější profesor a kratší čas i děkan právnické fakulty v Brně a také ústavní soudce. V jeho učební pomůcce bylo pár úvodních stránek, kde byly obsaženy „,povinné ideologické výhrady“ a pak následoval korektní popis ústavněprávního uspořádání v demokratických státech. Jako studenti jsme snadno vytušili, že součástí zkouškového procesu nebudou ony úvodní stránky. Byl to instruktivní návod i pro mé odborné práce a pedagogické počínání v určitém období. Zmíněnou učební pomůcku jsem si připomenul počátkem devadesátých let, když jsem již jako učitel brněnské právnické fakulty stážoval v mnichovském institutu Maxe Plancka. Měli tam už tehdy specialistu na Čínu a v jeho pracovně se nacházela i v Číně vydaná a v angličtině napsaná publikace o reklamě. Ta také obsahovala úvodní „,ideologické ohrazení“, které se distancovalo od reklamních praktik v kapitalistické cizině, načež následoval detailní popis takových praktik.

$\mathrm{S}$ dalším předmětem v pátém ročníku, bylo jím účetnictví, jsem měl jistou osobnější zkušenost. Přednášející (jméno si nevybavuji a z podpisu v indexu jsem vyluštil jen Ing. Dr.) nepřednášel vưbec suše, jak by se podle jeho předmětu dalo soudit. Skripta zvlášt' napsaná pro právníky měl jen v rukopise a mně připadl úkol (možná jeden z prípadů mé zbytečné horlivosti), abych zajistil přepis a rozmnožení těch skript. Ani se nepamatuji, jak vůbec se mi to podařilo ve stanoveném čase zvládnout. V textu této provizorní studijní pomůcky zůstalo několik překlepů, např́klad místo „rozvahová tabulka“ tam bylo napsáno „,rozvahová talveka“, což docela působilo jako odborný termín. Když pak zvlášt' dobře připravení studenti si při zkoušce vytáhli otázku „rozvahová tabulka“, byli na rozpacích, o co se vlastně jedná. Rozumný pedagog se brzy dopátral, v čem je problém. Nijak zvlášt' mi pak nevyčinil a zejména nezneužil ten překlep. Lísteček se zkouškovou otázkou z účetnictví obsahoval napříště text: „Rozvahová talveka (správně tabulka)“. To byl př́kladný př́stup učitele, který si váží svého oboru, má dobrý vztah ke studentům a nechce je přri zkoušce nachytat.

$\mathrm{Na}$ soubornou závěrečnou zkoušku z mezinárodněprávní specializace jsem se připravoval neobvyklým způsobem. Vedle povinné literatury mi náhoda přihrála románovou ságu „Konec světa - Lanny Budd“, kterou napsal Upton Sinclair. Český překlad tohoto díla mi prodala dáma z „lepších kruhư“, která se po smrti manžela ocitla ve finanční tísni. Román byl pro mne literárně zajímavý a i studijně užitečný, nebot' v něm autor 
líčil světové dějiny v období kolem první světové války. Dlouhé měsíce jsem si v té řadě svazků četl a zapisoval zajímavé postřehy i formulace, občas uváděné i v některém ze světových jazyků, jako např́iklad „fait accompli“‘. Jeden z poznatků nevšedně formulovaných se týkal i reparací po první světové válce, které měly být uloženy Německu. Představitel Francie Clemenceau, když hodlal vyjádřit podstatu sporných názorů, prý řekl: „Jedni chtějí krávu dojit a druzí zabít." Jiná náhoda pak tomu chtěla, že jsem si z dějin diplomacie „vytáhnul“ otázku „,reparace po první světové válce“. Zmíněnou myšlenku jsem použil a dodnes si vybavuji, jak na mne profesoři Bystrický i Outrata pohlédli překvapeným, vlídným úsměvem a pak už neměli další otázky.

$\mathrm{Na}$ závěrečnou zkoušku z občanského práva hmotného a procesního jsem se připravil důkladně, protože to byly obory, které mě bavily. Když profesor Štajgr vyhlašoval jejich výsledky, posteskl si na celkovou úroveň znalostí. Dodal však, že alespoň já jsem - jak se obrazně vyjádřil - ,zachránil čest praporu“. Cynik by řekl, že se mi vyplatila pravidelná účast na přednáškách profesora Štajgra; samotnému mi cosi takového přišlo na mysl.

Protože jsem při př́pravě na závěrečnou zkoušku věnoval menší pozornost trestnímu a správnímu právu, nemrzely mne „dvojky“ z těchto oborů. Uznával jsem je za spravedlivé. Napadlo mne sice, že by „červený diplom“ způsobil radost rodičům, ale takové pomyšlení jsem zahnal úvahou: „Alespoň mi nikdo nebude závidět a taková či onaká ,barva“ diplomu nebude významná pro mou budoucnost.“

O mém přšším pracovním uplatnění bylo rozhodováno v tehdejším umístěnkovém řízení. Jednoho dne si mne zavolala kádrová referentka fakulty a vlídně se mne zeptala, o jaký druh místa bych měl zájem. Protože otec mi tehdy nedoporučoval ani soud ani prokuraturu a silně pochyboval o mé možnosti působit v diplomacii, vyhrkl jsem bez velkého rozmýšlení: „V advokacii.“ Referentka shovívavě opáčila: „Tam by vás byla škoda...“ Nabídla mi místo v právním odboru plzeňské „Škodovky“ (tehdy „Závodech V. I. Lenina") s tím, že i tam uplatním poznatky z mezinárodněprávní specializace. Dodala, že věc již je předjednána s vedoucím právního odboru, který se byl seznámit s nabídkou absolventů. Př́jal jsem to jako „fait accompli“, již rozhodnutou věc. Otec pak byl velmi spokojen s takovým umístěním a řekl, že práce ve významném ekonomickém subjektu je tím nejlepším, co mne tehdy po škole mohlo potkat.

Měl pravdu. V právním odboru „Škodovky“ byla skupina „prvorepublikových“ zdatných právníků, kteří mi ochotně předávali poznatky o právnickém řemesle. Po několika rocích v zaměstnání jsem své pracovní zkušenosti začal využívat i v odborné publicistice. ${ }^{2}$ V roce 1968 mi v nakladatelství Orbis vydali knížku „Podnikový právník“. Do jednoho

2 Uveřejnil jsem např́klad články „Podnikový právník a podnikové zájmy“ (Právník, 1965, č. 1); Jak upravit úkoly a postavení podnikových právníkủ (Arbitráăñ praxe, 1965, č. 3); Jaké vzdělání pro podnikového právníka? (Socialistická zákonnost, 1965, č. 4). 
z jejích výtisků jsem připsal věnování určené „tiché společnici na této práci“. Mínil jsem tím manželku, která také byla jedním z celoživotních zisků mé umístěnky do Plzně. Zmíněné autorské činnosti se povšimli i v Ústavu státu a práva akademie věd a byla mi naznačena možnost, abych jako externista usiloval o tehdejší titul kandidáta právních věd. Tuto nabídku jsem bez váhání přijal a v roce 1970 dokončil a pozdẽji obhájil disertační práci na téma „Životní úroveň a občanskoprávní závazky“.

Zároveň jsem dále publikoval a v roce 1972 mi v Orbisu vyšla knížka „Jak uzavírat hospodářské smlouvy“. V ní jsem charakterizoval různé typy podnikových pracovníků a použil např́iklad označení „Právní mystik“ či „Právní sadista“, jak mne k tomu inspirovala manželka, povoláním lékařka v oboru psychiatrie a sexuologie. Působením v hospodářské praxi a publikováním postřehů z ní jsem si vytvořil nejen jisté odborné renomé, ale získal i zásobárnu poznatků a př́kladů, které se daly dobře využít v pedagogické činnosti.

V té době mi přišla nabídka učitelského místa na právnické fakultě v Brně. Tentokráte nebyla má reakce okamžitá. Dost dlouho jsem váhal. Ve „Škodovce“ jsem měl slušně placené a možná i perspektivní místo. V Plzni jsme již byli zabydleni (včetně tehdejšího „luxusu“ jakým byla zahrádka a chatka u blízkého rybníka); také dočasné odloučení a přesun s třemi malými dětmi se jevily jako náročné. Psal jsem si rozhodovací tabulky a pod hesly „ano“ - „ne“ postupně doplňoval či škrtal určité argumenty. Ty jsem pak zjednodušil na jedinou otázku: „Co by mne víc bavilo?“ Odpověd’ na ni pak byla dost jednoznačná a podpořila mne v ní i manželka, v jejíž rodině bylo povícero vědeckých pracovníků i učitelů na všech stupních vzdělávací soustavy. Věděli jsme oba, že pedagogická i vědecká činnost mne bude zajímat. Předpokládali jsme také, že se mi podaří nalézt dobrý vztah ke studentům. Není již na mně, abych hodnotil, zda a jak se takový předpoklad naplnil. Nikdy jsme však s manželkou svého rozhodnutí nelitovali. 